of certain classes of molecules are collected below : $\mathrm{H}_{2} \mathrm{O}, 12.56 ; \quad \mathrm{CH}_{3} \mathrm{OH}, 10 \cdot 8 ; \quad \mathrm{C}_{2} \mathrm{H}_{5} \mathrm{OH}, 10 \cdot 7$; $\mathrm{C}_{3} \mathrm{H}_{7} \mathrm{OH}, 10.7 ; \quad\left(\mathrm{CH}_{3}\right)_{2} \mathrm{O}, 10.5 ; \quad\left(\mathrm{C}_{2} \mathrm{H}_{5}\right) \mathrm{O}, 10 \cdot 2$; $\mathrm{H}_{2} \mathrm{~S}, \mathrm{I0} \cdot 42 ; \mathrm{C}_{2} \mathrm{H}_{5} \mathrm{SH}, 9 \cdot 7 ;\left(\mathrm{CH}_{3}\right)_{2} \mathrm{~S}, 9 \cdot 4 ;\left(\mathrm{C}_{2} \mathrm{H}_{5}\right)_{2} \mathrm{~S}$, $9 \cdot 3 ; n\left(\mathrm{C}_{3} \mathrm{H}_{7}\right)_{2} \mathrm{~S}, 9 \cdot 2 ;$

$\mathrm{NH}_{3}, 10 \cdot 8 ; \mathrm{CH}_{3} \mathrm{NH}_{2}, 9 \cdot 8 ;\left(\mathrm{CH}_{3}\right)_{2} \mathrm{NH}, 9 \cdot 6 ;\left(\mathrm{CH}_{3}\right)_{3} \mathrm{~N}, 9 \cdot 4$; $\mathrm{H}_{2} \mathrm{CO}, 10.83 ; \mathrm{CH}_{3} \mathrm{CHO}, 10.181 ;\left(\mathrm{CH}_{3}\right)_{2} \mathrm{CO}, 10 \cdot 1$; $\mathrm{CH}_{2} \mathrm{CHCHO}, 10 \cdot 06$;

$\mathrm{CH}_{3} \mathrm{CHCHCHO}, 10 \cdot 19$;

$\mathrm{CH}_{3} \mathrm{CCH}, 11 \cdot 25$; $\mathrm{HCCCCH}, 10 \cdot 74$;

$\mathrm{H}_{2} \mathrm{CCHCl}, 9 \cdot 95$; ClHCCHCl, 9.6I (cis), $9 \cdot 91$ (trans) ; $\mathrm{C}_{6} \mathrm{H}_{6}, 9 \cdot 19 ; \mathrm{C}_{12} \mathrm{H}_{10}, 8 \cdot 3 ; \mathrm{C}_{6} \mathrm{H}_{5} \mathrm{CH}_{3}, 8 \cdot 77 ; \mathrm{C}_{6} \mathrm{H}_{4}\left(\mathrm{CH}_{3}\right)_{2}$ $(0, m$ and $p), \sim 8 \cdot 3$ electron volts.

Values given to $0.01 \mathrm{v}$. are spectroscopic, the others are electron impact values. For $\mathrm{H}_{2} \mathrm{O}, \mathrm{H}_{2} \mathrm{~S}, \mathrm{H}_{2} \mathrm{CO}$ and their alkyl derivatives the electron removed is a non-bonding $p \pi$ oxygen (or sulphur) electron. For $\mathrm{NH}_{3}$ and the amines the minimum ionization potential corresponds to a $2 p_{z}(\mathrm{n})$ electron, which is non-bonding with orbital perpendicular, to H.H. plane ${ }^{1}$. In methyl acetylene, diacetylene, the halogenated ethylenes and the aromatic molecules, $\pi$ electrons of the double and triple bonds are involved, these being modified by resonance in molecules where conjugation occurs.

For acetaldehyde, acrolein and crotonaldehyde, very extensive Rydberg series were found in the vacuum ultra-violet, enabling the ionization potentials of these molecules to be obtained with unprecedented accuracy. One of the Rydberg series found for acetaldehyde contained sixteen members and gave a limit corresponding to $10 \cdot 1811 \pm 0 \cdot 0007 \mathrm{v}$. This is the most accurate ionization potential so far determined for a polyatomic molecule. A fifteen membered series was obtained for erotonaldehyde giving an ionization potential of $10 \cdot 187 \pm 0 \cdot 001 \mathrm{v}$. and a series of ten members in acrolein converging to a limit of $10 \cdot 057 \pm 0 \cdot 006 \mathrm{v}$.

T. M. SUGden.

A. D. Walsh.

Physical Chemistry Laboratory, W. C. PRICE. The University, Cambridge.

${ }^{1}$ R. S. Mulliken, J. Chem. Phys., 3, 506-14 (1935).

\section{Carotenoids of Grass Silage}

WHEN using Moon's ${ }^{1}$ method for the estimation of 'crude carotene' in routine silage samples, we have applied Moore's ${ }^{2}$ chromatographic technique for removing other chromogens from the carotene solution, as obtained by Moon's method, in order to obtain a value for 'pure carotene'. In the case of silages the 'pure carotene' values may be considerably less than the 'crude carotene' values.

Latterly we have sought to replace the customary phase separation of 'crude carotene' and xanthophylls by using the same chromatographic technique for the removal of xanthophylls as well as of non-carotene chromogens from the petrol ether solution.

Values for 'pure carotene' obtained by $(a)$ passing the petrol ether solution of 'crude carotene' after phase separation of xanthophylls through a column of dicalcic phosphate (prepared as recommended by Moore $^{2}$ ) and by (b) passing the original petrol ether solution of total carotenoids through a similar column were in close agreement. For routine carotene estimations on silage, procedure $(b)$ has the advantage of avoiding the phase separation.
The chromatograms of a series of samples of laboratory grassland silage examined in this way displayed an interesting feature. From the fourth day after ensiling, a well-defined blue-green band about $1 \mathrm{~mm}$. wide appeared some $5 \mathrm{~mm}$. below the strongly adsorbed 'xanthophyll' band at the top of the column. While attempting to repeat this observation on later samples, this band was not always obtained at once, but a light yellow band of the same thickness appeared in the same position on the column. On sucking off the petrol ether from the column this yellow band changed in the course of 3-5 hours to the same blue-green as originally observed.

This ready isolation of a blue-green chromogen from the petrol ether solution of the carotenoids of grassland silage may have a bearing on the production of 'grass yolks' in eggs from hens fed on silage ${ }^{3}$.

A seasonal incidence of olive-tinted yolks has also been observed in egg-packing stations in Northern Ireland. In one case it was found that the birds were ranging on young pasture rich in suckling clover; the incidence of the olive tint was cured by shutting the birds off from pasture for a time.

It seems possible that the cause of this seasonal incidence of olive-tinted yolks may lie in the special richness of early summer pasture in carotenoids, together with factors increasing the lability of the carotenoids and favouring the production of carotenoid derivatives of blue or blue-green colour. One such factor might be acidity, present alike in grass silage and in the fowl's crop.

W. Bouton.

R. H. Common.

Chemical Research Division,

Ministry of Agriculture for Northern Ireland, Queen's University, Belfast. Aug. 20.

${ }^{1}$ Moon, F. F., J. Agric. Sci., 29, 295 (1939).

${ }^{2}$ Moore, L. A., Ind. Fing. Chem., Anal. Ed., 12, 726 (1940). ${ }^{3}$ Gish, C. T., Payne, L. F., and Peterson, W. J., Poultry Sci., 19, 154

\section{Polygenic Variability in Wild Drosophila melanogaster}

Several authors have reported the recovery of variant types by inbreeding Drosophila melanogaster caught in the wild. The mutations described have generally been of single major genes, recognized either by their obvious morphological or lethal effects ; inverted sections of the chromosomes have also been found. The literature of the subject has been reviewed by Dobzhansky ${ }^{1}$.

Adaptation and speciation, however, chiefly depend on the action of selection upon what has been called quantitative, or more recently polygenic, variation ${ }^{2}$. Many genes, each having a small effect, control this type of variation, which probably affects all characters showing a range of apparently continuous variation. Such polygenic variation has now been shown to exist in wild populations of $D$. melanogaster.

Flies were trapped in various parts of southern England in the summer of 1940. Two strains derived from flies caught at Ockley and Ealing respectively were subjected to selection for increase and decrease of the number of chætæ in the sternopleural regions. Dubinin and collaborators ${ }^{3}$ have shown that populations from different parts of the U.S.S.R. have characteristic and different numbers of sternopleural chætæ, and my own experiments (unpublished) have shown the variation to be polygenic. 